\title{
Development of natural fermented seasoning with Flammulina velutipes powder fortified with $\gamma$-aminobutyric acid (GABA) by lactic acid fermentation
}

\author{
Eun-Jin Park ${ }^{1}$, Syng-Ook Lee ${ }^{1}$, Sam-Pin Lee ${ }^{1,2 *}$ \\ ${ }^{1}$ Department of Food Science and Technology, Keimyung University, Daegu 42601, Korea \\ ${ }^{2}$ The Center for Traditional Microorganism Resource (TMR), Keimyung University, Daegu 42601, Korea
}

\section{팽이버섯(Flammulina velutipes) 분말의 젖산발효를 통한 고농도 $\mathrm{x}$-aminobutyric acid 함유 천연 발효조미료 개발}

\author{
박은진 ${ }^{1} \cdot$ 이승욱 ${ }^{1} \cdot$ 이삼빈 ${ }^{1,2 *}$ \\ ${ }^{1}$ 계명대학교 식품가공학전공, ${ }^{2}$ 계명대학교 전통미생물자원개발 및 산업화지원센터
}

\begin{abstract}
Lactic acid fermentation of Flammulina velutipes (FV) powder was optimized to produce higher content of $\mathrm{\gamma}$ -aminobutyric acid (GABA). FV powder (10\%) was fermented with $0.5 \%$ yeast extract, $1 \%$ glucose, $5 \%$ mono sodium-L-glutamate (MSG) by Lactobacillus plantarum EJ2014 for 5 days at $30^{\circ} \mathrm{C}$. The pH decreased from 6.1 to 4.4 for first 2 days after then increased to 6.2 for following 5 days. While the acidity increased from $0.5 \%$ to $1.3 \%$ for 2 days, after then decreased to $0.4 \%$ for 5 days. Viable cell count showed higher value of $2.2 \times 10^{9}$ CFU/mL after fermentation for 5 days. In particular, 3.54\% MSG as a substrate was completely utilized during lactic acid fermentation, indicating higher $2.31 \%$ GABA content. The fermented FV powder showed higher antioxidant properties than that of un-fermented $\mathrm{FV}$ power. $\mathrm{IC}_{50}$ values of $\mathrm{DPPH}$ radical scavenging and $\mathrm{ABTS}$ radical scavenging activities were $1.11 \mathrm{mg} / \mathrm{mL}$ and $2.58 \mathrm{mg} / \mathrm{mL}$, respectively. Conclusively, natural fermented seasoning from the lactic acid fermentation of $30 \mathrm{~g}$ of $\mathrm{FV}$ powder and $1 \mathrm{~g}$ of roasted wheat bran could provide the functional ingredients with $17 \%$ GABA, probiotics and dietary fiber, which is used for health food and functional seasoning.
\end{abstract}

Key words : Flammulina velutipes, Lactobacillus plantarum, $\mathrm{y}$-aminobutyric acid, antioxidant effect, seasoning

\section{서 론}

팽이버섯(Flammulina velutipes)은 분류학적으로 담자균 류 주름버섯목 송이과에 속하며 전 세계적으로 분포하지만 특히 아시아 지역에서 많이 재배되는 식용버섯이다(1). 팽 이버섯은 맛과 향기가 우수할 뿐만 아니라, 단백질, 아미노 산, $\beta$-glucan, 비타민 및 미량 원소 등을 함유하고 있다(2).

*Corresponding author. E-mail : splee@kmu.ac.kr

Phone : 82-53-580-5554, Fax : 82-53-580-5729

Received 3 March 2017; Revised 30 March 2017; Accepted 10 April 2017.

Copyright (c) The Korean Society of Food Preservation. All rights reserved.
또한 항암작용이 있는 것으로 보고된 flammulin과 혈압강 하 작용이 있는 flammutoxin을 함유하고 있어 항바이러스 및 항종양, 콜레스테롤 저하작용 등에 도움이 된다고 알려 져 있다(3-6). 일반적으로 버섯은 다양한 효소의 활성이 높 고 조직이 연하기 때문에 색상과 조직의 변화로 인해 저장 에 어려움이 있어 저장성을 향상시키기 위해 버섯을 건조시 켜 식품의 첨가제 및 분말형태로도 사용을 하고 있다 $(7,8)$. 최근에는 건강지향적인 소비자들이 조미료 시장에서 화학 복합조미료 보다는 다양한 천연조미료 제품에 높은 관심을 보이면서 버섯류가 각종 조리 및 가공 식품의 조미료 소재 로서 이용이 증가되고 있는 추세이다.

팽이버섯의 품질 및 기능성을 향상시키기 위하여 다양한 연구가 진행되었으며, Lee 등(9)은 녹차를 이용하여 재배한 
팽이버섯의 이화학적 특성을 보고하였고, $\operatorname{Kim}$ 등(10)은 반 응표면분석에 의한 팽이버섯의 microwave를 이용한 추출 조건 최적화를 보고하였다. 지금까지 가공 및 추출물의 기 능성에 대한 연구가 활발하게 진행된 반면에 발효기술을 이용한 팽이버섯의 기능성 향상을 위한 연구는 미비한 실정 이다.

발효는 동서양에서 저장성과 풍미 등을 개선하기 위해 사용해온 전통기술로써 다양한 유용 미생물이 지역의 고유 한 원료에 작용하여 독특한 맛과 기능성이 강화된 발효식품 을 만드는데 기여하고 있다. 특히 유산균은 대표적인 probiotics로서 당질을 이용하여 발효 산물로 유기산, 알코 올, $\mathrm{CO}_{2}$ 등을 생성하며, 정장작용을 통한 장내 기능 향상 및 면역증진 효과가 밝혀지면서 건강소재로 관심이 높아지 고 있다(11).

Lactobacillus plantarum 등의 발효식품 유래 젖산균에 의해 생산이 되는 $\gamma$-aminobutyric acid(GABA)는 비단백질 구성 아미노산으로 뇌에서 신경전달물질로서의 역할뿐 아 니라 뇌의 혈류를 개선하고 산소 공급을 증가시켜 중풍과 치매 예방, 기억력 증진, 혈압강하작용, 우울증 완화 등에 효과가 있는 것으로 알려져 있어 brain food라고 한다 (12-14). GABA는 식물체에도 함유되어 있어 발아현미, 녹 차 등을 경구적으로 섭취가 가능하지만, 자연에서 존재하 는 미량의 GABA 섭취를 통해서 생리작용의 효과를 기대하 기는 어렵다(15). 최근 건강소재로 중요하게 인식되는 $\mathrm{GABA}$ 를 천연소재의 발효 최적화를 통해서 고농도로 생산 하며, 특히 다양한 젖산균을 이용한 발효방법을 통해서 $\mathrm{GABA}$ 를 대량 생산하는 연구가 보고되었다 $(16,17)$.

따라서 $\mathrm{GABA}$ 를 생산하는 균주인 Lactobacillus plantarum $\mathrm{EJ} 2014$ 를 이용하여 기호식품으로 각광 받고 있는 팽이버섯 분말의 젖산발효 최적화를 통해서 고농도 $\mathrm{GABA}$ 생산을 수행하였으며, 가공 공정을 통하여 고농도 $\mathrm{GABA}$, 식이섬 유, probiotic을 포함하며 항산화 효과를 가진 기능성 팽이버 섯 천연 발효조미료를 개발하는 기초 연구 자료를 제공하고 자 하였다.

\section{재료 및 방법}

재 료

본 연구에서 사용된 팽이버섯 분말은 농업회사법인 (주) 늘그린(Goryeong, Korea)에서 구입하였고, 팽이버섯 발효 물을 생산하는 배지의 영양성분으로 glucose는 Ducksan (Ducksan pure chemical co., Ansan, Korea)에서 구입하였으며, 생육 촉진제로서 yeast extract(YE)는 조흥(주)(Ansan, Korea)제품을 사용하였다. GABA 생산의 기질로 사용한 monosodium L-glutamate(MSG)는 Yakuri Pure Chemicals Co., LTD.(Kyoto, Japan)에서 구입하였으며, 분석에 사용된
시약은 특급이상 시약들을 사용하였다.

팽이버섯 분말 입도 분석

입자크기 분석은 $10 \%$ 팽이버섯 분말액을 증류수로 10 배 희석한 후 Zeta-potential \& particle size analyzer ELSZ2000(Otsuka Electronics Co., Ltd, Otsuka, Japan)를 사용하 여 측정하였다.

\section{수분용해지수와 수분흡착지수}

팽이버섯 분말의 수분용해지수(water soluble index, $\mathrm{WSI}$ )와 수분흡착지수(water absorption index, WAI)를 측정 하였다. 수분용해지수는 시료 $1 \mathrm{~g}$ 에 증류수 $20 \mathrm{~mL}$ 를 가하여 Intelli mixer로 1 시간 교반 후 $8,000 \mathrm{rpm}$ 으로 20 분간 원심분 리 하였다. 원심분리 후 회수된 상등액을 건조기에 $105^{\circ} \mathrm{C}$ 에 서 4시간 동안 건조하고 건조된 시료를 무게를 측정하여 건조시료에 대한 백분율로 나타내었다. 수분흡착지수는 상 등액을 제외한 침전물의 무게를 측정하여 건조시료 $\mathrm{g}$ 당 흡수된 수분량으로 표시하였다.

$$
\begin{aligned}
& \mathrm{WSI}(\%)=\frac{\text { 건조한 상등액 시료무게 }(\mathrm{g})}{\text { 처음 시료 무게 }(\mathrm{g})} \times 100 \\
& \mathrm{WAI}(\mathrm{g} / \mathrm{g})=\frac{\text { 침전 후 시료무게 }(\mathrm{g})-\text { 처음 시료 무게 }(\mathrm{g})}{\text { 처음 시료 무게 }(\mathrm{g})}
\end{aligned}
$$

팽이버섯 분말액의 점조도 측정

점조도는 Rheometer system(HAKKE RheoStress 1, Thermo, Karlsruhe, Germany)에 cone plate device(Plate $\mathrm{PP} 35 \mathrm{Ti}, 3.5 \mathrm{~cm}$ diameter)를 장착한 다음 측정하였다. $10 \%$ 팽이버섯 분말액 $1 \mathrm{~mL}$ 을 원형 plate에 고루 퍼지게 한 다음 cone plate를 하강시켜 시료와 $1 \mathrm{~mm}$ 간격으로 유지시켰다. 전단속도(shear rate, $1 / \mathrm{s}$ ) 변화에 따른 전단응력(shear stress, $\mathrm{Pa}$ ) 값을 구간 당 10 초 동안의 평균값을 측정하여 점조도 값을 평가하였다. 측정 온도는 $20^{\circ} \mathrm{C}$ 에서 전단속도(ケ́)는 1-100 s-1의 범위로 유동특성을 알아보고자 하였고, 점조도 지수는 Power law model로 평가하였다.

Power law model $: \sigma=\mathbf{K} \cdot \hat{\Gamma}^{\mathrm{n}}$

$\sigma$ 는 전단응력(shear stress, $\mathrm{Pa}), \mathrm{K}$ 는 점조도 지수

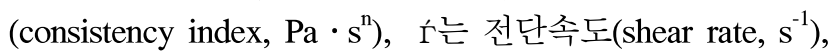
$\mathrm{n}$ 은 유동성 지수(flow behavior index)이다.

사용균주 및 스타터 배양액 제조

Lactobacillus plantarum EJ2014는 미강(Uljin, Korea)으 로부터 시료 $2 \mathrm{~g}$ 을 멸균 증류수 $18 \mathrm{~mL}$ 에 혼합한 후 $10^{3}$ 배까 지 희석하고 Difco $^{\mathrm{TM}}$ Lactobacilli MRS broth agar(Becton, 
Dickinson and Company, Sparks, MD, USA)에 도말하여 $30^{\circ} \mathrm{C}$ 항온배양기(IS-971R, Jeio tech., Kimpo, Korea)에서 24시간 배양하여 균주를 순수 분리하였다(18). 균주의 단일 콜로니를 취하여 1회 MRS agar에서 계대배양한 후, $121^{\circ} \mathrm{C}$ 에서 15 분간 멸균한 MRS broth에 순수 분리된 L plantarum $\mathrm{EJ} 2014$ 를 한 백금이를 접종하여 $30^{\circ} \mathrm{C}$ 에서 24 시간 정치배양 한 뒤 스타터로 사용하였다.

\section{팽이버섯 분말의 젖산발효}

팽이버섯 분말 $10 \mathrm{~g}$ 과 영양성분인 YE $0.5 \mathrm{~g}$, glucose 1 $\mathrm{g}$, MSG 0-5 g에 증류수 $100 \mathrm{~mL}$ 을 넣은 후 $121^{\circ} \mathrm{C}$ 에서 15 분간 열처리 하였다. 그 다음 L. plantarum EJ2014 starter를 $1 \%$ 접종 후 $30^{\circ} \mathrm{C}$ 에서 5 일간 정치 배양하여 팽이버섯 분말의 발효물을 제조하였다.

\section{$\mathrm{pH}$, 산도 및 생균수 측정}

pH는 $\mathrm{pH}$ meter(model $420+$, Thermo Orion, Washington $\mathrm{DC}, \mathrm{USA}$ )로 측정하였다. 적정 산도는 시료를 $1 \mathrm{~mL}$ 에 증류 수 $9 \mathrm{~mL}$ 을 첨가하여 $0.1 \mathrm{~N} \mathrm{NaOH}$ 로 $\mathrm{pH} 8.3$ 까지 적정한 소비량을 젖산 함량 $(\%, \mathrm{v} / \mathrm{v})$ 으로 환산하였다.

생균수는 발효물 $1 \mathrm{~g}$ 에 $9 \mathrm{~mL}$ 의 멸균수를 첨가하여 10 배 희석법을 이용하여 $10^{4}, 10^{5}, 10^{6}$ 배로 희석된 것을 $\mathrm{MRS}$ agar plate에 $20 \mu \mathrm{L}$ 도말한 다음 $30^{\circ} \mathrm{C}$ 항온배양기에서 24시 간 배양한 후 생균수를 colony forming unit $(\mathrm{CFU} / \mathrm{mL})$ 로 나 타내었다.

\section{$\mathrm{GABA}$ 함량 측정}

MSG 및 $\mathrm{GABA}$ 의 정성 분석을 위해 silica gel thin layer chromatography(TLC) plate는 $10 \times 20 \mathrm{~cm}$ 로 잘라서 사용하였 고, TLC 용매 전개는 사각 $\operatorname{chamber}(30 \times 25 \times 10 \mathrm{~cm})$ 에서 수 행하였다. MSG 잔존량과 GABA 함량 비교를 위한 standard 로 MSG $0.25,0.5,1,2 \%$ 와 GABA $0.25,0.5,1,2 \%$ 를 사용하 였다. 전개용매는 n-butyl alcohol:acetic acid glacial:distilled water를 3:1:1(v/v)의 비율로 혼합하여 실온에서 4시간 이상 포화시켰다. 발효물 시료와 standard 용액을 TLC plate의 아래에서 $15 \mathrm{~mm}$ 되는 위치에 $2 \mu \mathrm{L}$ 를 점적하였고, 간격은 10-15 mm를 유지하였다. 그 다음 TLC plate의 sample을 건조시켜 전개하였고, 전개가 끝난 TLC plate는 상온에서 건조시킨다. 건조 된 TLC plate에 발색시약인 $0.2 \%$ ninhydrin 용액을 뿌리고, $100^{\circ} \mathrm{C}$ 건조기에서 약 5 분 동안 발색 시킨 다음 발효물의 $\mathrm{MSG}$ 와 GABA spot을 확인하였다.

$\mathrm{GABA}$ 전환율을 확인하기 위한 유리아미노산 함량을 HPLC로 분석하였다. 건조시킨 시료를 PITC(phenylisothiocyanate)용액 $20 \mu \mathrm{L}\left(\mathrm{MeOH}: \mathrm{H}_{2} \mathrm{O}: \mathrm{TEA}: \mathrm{PITC}=7: 1: 1: 1\right)$ 를 유도체화 시킨 뒤 상온에서 30 분간 반응시킨다. 시료를 완 전히 말린 후 $200 \mu \mathrm{L}$ 의 A solvent로 녹이고 원심분리 시킨 후 상등액을 $0.45 \mu \mathrm{L}$ syringe filter로 여과한 후 분석하였다.
아미노산 분석은 HPLC 장치(Hewlett Packard 1100 Series, PaloAlto, CA, USA)에 $\mathrm{C}_{18}$ column(Waters Nova-Pak $\left.4 \mu \mathrm{m}\right)$ 을 장착한 후 mobile 용매는 각각 $\mathrm{A}(140 \mathrm{mM} \mathrm{NaHAc}, 0.15 \%$ TEA, $0.03 \%$ EDTA, $6 \% \mathrm{CH}_{3} \mathrm{CN}$, pH6.1) $100 \%$ 로 elution후 25 분 동안 $\mathrm{B}\left(60 \% \mathrm{CH}_{3} \mathrm{CN}, 0.015 \% \mathrm{EDTA}\right) 100 \%$ 가 되도록 혼합하면서 분당 $1 \mathrm{~mL}$ 로 흘려주었다. 아미노산 측정은 254 $\mathrm{nm}$ 에서 $\mathrm{UV}$ 흡광도를 측정하였다.

\section{$\mathrm{DPPH}$ radical 소거활성 측정}

팽이버섯 발효물의 DPPH radical 소거활성 비교를 위해 팽이버섯 분말에 L. plantarum EJ2014를 접종하기 전과 후 의 발효물을 원심분리 $(13,000 \mathrm{rpm}, 10 \mathrm{~min})$ 하여 얻은 상등 액을 실험에 사용하였다. 팽이버섯 분말 발효 전과 발효 후의 상등액 $160 \mu \mathrm{L}$ 와 에탄올에 녹인 $0.15 \mathrm{mM} \mathrm{DPPH}$ 용액 $40 \mu \mathrm{L}$ 를 가하여 실온에서 30 분 방치한 후 $517 \mathrm{~nm}$ 에서 흡광 도를 측정하였다. 각 시료 추출물의 유리 라디칼 소거활성 은 시료를 첨가하지 않은 대조구의 흡광도를 $2 / 1$ 로 환원시 키는데 필요한 시료의 농도인 $\mathrm{IC}_{50}$ 값으로 나타내었다. 이 때 상대 활성의 비교를 위하여 대조군으로 butylated hydroxy anisole(BHA)를 사용하였다.

\section{ABTS radical 소거활성 측정}

$7 \mathrm{mM}$ 2,2-azino-bis(3-ethylbenzthiazoline-6-sulfonic acid) 와 $2.45 \mathrm{mM}$ potassium persulfate를 최종농도로 혼합하여 실온인 암소에서 24시간 동안 방치하여 $\mathrm{ABTS}+$ 을 형성시 킨 후 $732 \mathrm{~nm}$ 에서 흡광도 값이 $0.70 \pm 0.02$ 이 되게 phosphate buffer saline(PBS, $\mathrm{pH}$ 7.4)로 희석하였다. 희석된 용액 180 $\mu \mathrm{L}$ 에 팽이버섯 분말 발효 전과 후의 발효물을 원심분리 $(13,000 \mathrm{rpm}, 10 \mathrm{~min})$ 하여 얻은 상등액 $20 \mu \mathrm{L}$ 를 가하여 정확 히 1 분 동안 방치한 후 흡광도를 측정하였다.

\section{통계처리}

실험 결과는 SPSS 23.0(SPSS Inc., Chicago, IL, USA) 통계 프로그램을 이용하여 분산분석(ANOVA test)을 실시 하였고, Duncan's multiple range test를 적용하였다. 결과에 대한 검증은 $\mathrm{p}<0.05$ 수준에서 검증하였다.

\section{결과 및 고찰}

팽이버섯 분말액의 성분분석

팽이버섯 분말의 $10 \%$ 분산액을 이용하여 팽이버섯 분말 입자 크기를 측정한 결과 $52.98 \pm 11.56 \mu \mathrm{m}$ 범위로 나타났으 며 수분흡착지수는 $2.58 \pm 0.29$ 로, 수분용해지수는 $47 \pm 0.00 \%$ 로 확인되었다. $\mathrm{pH}$ 는 6.65 , 산도는 $0.16 \%$, 수용성 고형분 함량은 $5.77{ }^{\circ} \mathrm{Brix}$ 를 나타내었으며 점조도 값은 $2.86 \mathrm{~Pa} \cdot \mathrm{sn}$ 로 나타났다. 
팽이버섯 분말 함량에 따른 젖산발효 최적화

젖산균은 정장작용이 있는 대표적인 probiotic으로서 변 비, 설사 등의 각종 특정 질환을 예방하는데 이용되고 있으 며(19), 젖산균을 이용한 식품소재의 발효를 통해서 생산되 는 젓산, 다당류 등은 식품의 풍미, 맛, 조직감 등을 향상시 킬 뿐만 아니라 병원성 미생물의 성장을 억제시킴으로서 식품의 안전성 및 저장성을 부여한다 $(20,21)$.

젓산균 생육을 증진시키기 위해 복합 영양성분으로 $0.5 \%$ yeast extract 첨가 시에 발효과정 중에 배양액의 당도가 크게 감소하면서 젖산발효가 효과적으로 수행된 연구결과 와(18), 젓산발효 시 glucose $1 \%$ 수준의 당 첨가가 산 생성을 비롯하여 젓산발효에 도움을 주는 것으로 연구결과가 보고 되었다(22).

이를 바탕으로 팽이버섯 분말을 이용하여 효과적인 $\mathrm{GABA}$ 생산을 위한 젓산발효의 선행연구로서 $0.5 \% \mathrm{YE}, 1 \%$ glucose 조건에서 GABA생산을 위한 기질로서 $2 \% \mathrm{MSG}$ 를 첨가하여 팽이버섯 분말 함량에 따른 발효를 수행하였다. 팽이버섯 분말 $10 \%$ 첨가한 조건이 발효 5 일째 까지 산도 $1.07 \%$, 생균수는 발효 3 일까지 $1.0 \times 10^{9} \mathrm{CFU} / \mathrm{mL}$ 로 유지되 다가 5 일째 감소하는 것으로 나타났다. 팽이버섯분말의 농 도가 높을수록 생균수는 높게 유지되는 경향을 보였으나 팽이버섯 분말의 농도가 증가함에 따라 점성을 나타내면서 배지의 멸균 시에 끓어 넘치는 현상이 있어 팽이버섯 분말 $10 \%$ 농도가 젓산발효 시 최적 조건으로 판단되었다. TLC 를 이용하여 $\mathrm{GABA}$ 정성분석 한 결과 팽이버섯 분말 $10 \%$ 를 첨가하였을 때 발효 3일째 $\mathrm{MSG}$ 가 모두 $\mathrm{GABA}$ 로 전환되는 것을 확인 할 수 있었다(data not shown). 따라서 팽이버섯 분말을 $10 \%$ 첨가한 조건에서 고농도 $\mathrm{GABA}$ 생산을 위한 젖산발효 최적화 연구를 수행하였다.

\section{$\mathrm{MSG}$ 함량에 따른 $\mathrm{pH}$, 산도 및 $\mathrm{GABA}$ 생산}

팽이버섯 분말을 $10 \%$ 함유한 천연 배지조건에 MSG 함 량을 $0,1,3,5 \%$ 수준으로 첨가하여 정치 배양시킨 후에 발효물의 $\mathrm{pH}$ 및 산도를 측정해 본 결과 발효 전의 $\mathrm{pH}$ 는 $\mathrm{MSG}$ 농도와 관계없이 약 $\mathrm{pH}$ 6으로 비슷하였다. 그러나 젖산 발효가 진행되면서 $0 \%, 1 \%, 3 \%$ 수준으로 $\mathrm{MSG}$ 가 첨가된 팽이버섯 발효물은 발효 1 일에 $\mathrm{pH}$ 가 각각 $3.7,4.0$, 4.3으로 크게 낮아진 후 발효 3 일 동안 유지하는 경향을 보였다. 반면에 $5 \% \mathrm{MSG}$ 첨가는 발효 1 일차에 $\mathrm{pH}$ 4.4로 떨어진 후 발효 5 일째 $\mathrm{pH}$ 6.2로 크게 증가하는 것으로 나타 났다(Fig. 1). 이는 김치에서 분리된 젖산균을 이용하여 발 효중에 $\mathrm{MSG}$ 첨가 없는 배지에서 $\mathrm{pH}$ 가 크게 감소하는 반면 에 $5 \% \mathrm{MSG}$ 를 첨가한 경우에 $\mathrm{pH}$ 가 상승한다는 연구보고와 유사한 결과를 나타내었다(23). 팽이버섯 발효 전의 산도는 약 $0.3 \%$ 로 나타났으며, $0 \%, 1 \% \mathrm{MSG}$ 를 첨가한 발효물은 발효 1 일에 모두 $1.0 \%$ 로 증가된 후 발효시간이 증가되면서 산도가 점점 증가하여 발효 5 일에 각각 약 $1.36 \%, 1.40 \%$ 를
나타내었다. $3 \%, 5 \% \mathrm{MSG}$ 를 첨가한 조건에서 젖산 발효물 은 발효 1 일차에 산도는 약 $1.2 \%, 1.3 \%$ 로 증가하다가 발효 5 일에 각각 $1.1 \%, 0.4 \%$ 로 크게 감소하였다(Fig. 2). 따라서 발효시간이 지남에 따라 $\mathrm{pH}$ 가 급격하게 증가하고, 산도는 급격하게 감소하는 $5 \% \mathrm{MSG}$ 를 첨가한 조건에서 $\mathrm{GABA}$ 가 생산 되었을 것이라고 판단되었다.

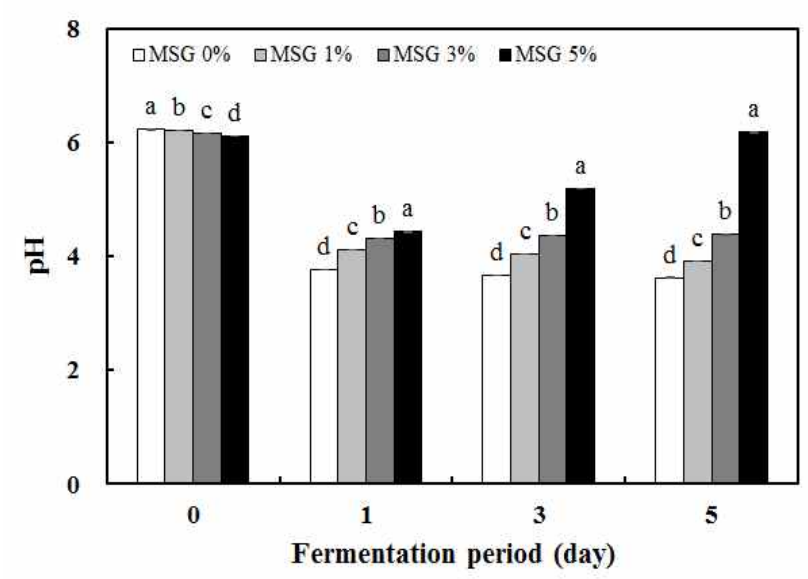

Fig. 1. Effect of MSG concentration on $\mathrm{pH}$ of Flammulina velvtipes powder fermented by $L$. plantarum EJ2014.

Each value is a mean $\pm S D(n \geq 3)$. Different letters ${ }^{\text {add }}$ in the same fermentation time mean significant difference by Duncan's multiple range test $(\mathrm{p}<0.05)$.

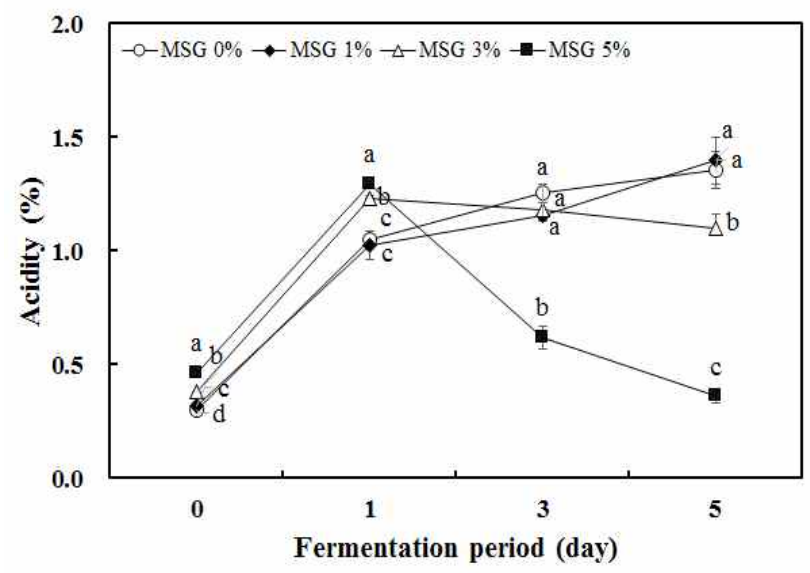

Fig. 2. Effect of MSG concentration on acidity of Flammulina velvtipes powder fermented by $L$. plantarum EJ 2014 .

Each value is a mean $\pm S D(n \geq 3)$. Different letters ${ }^{\text {ad }}$ in the same fermentation time mean significant difference by Duncan's multiple range test $(p<0.05)$.

L. plantarum은 발효성 당으로부터 젖산만을 생성하는 Homo형 균주로서 발효물의 산도를 높이는 대표적인 젖산 발효 미생물이다. 그러나 팽이버섯 분말의 젓산발효에서 젖산균의 생육에도 불구하고 산도가 감소하는 것은 일반적 인 젖산발효의 결과와는 다른 양상으로 젖산 발효가 진행되 면서 산성을 나타내는 유기산의 일부가 소비되는 것으로 판단되었다. 
또한 젖산발효에서 $\mathrm{GABA}$ 생산을 위해 첨가되는 전구물 질인 $\mathrm{MSG}$ 는 중성의 아미노산으로서 $3 \%$ 이상의 농도로 첨가하는 경우에 GABA로 전환 시 발효물의 산도를 유지 또는 감소시키는 경향을 나타내었는데, 이는 미생물의 환 경적인 스트레스를 극복하는 과정에서 젖산균은 높은 산에 대한 내성을 갖기 위해서 배양물에 존재하는 수소이온을 소비하면서 glutamate decarboxylase(GAD)효소작용으로 glutamic acid를 GABA로 전환시키기 때문인 것으로 보고 되었다(24). 젖산균에 의한 산 생성과 이에 따른 $\mathrm{pH}$ 감소는 일반적인 젖산발효 현상이지만, 젖산균에 의한 $\mathrm{GABA}$ 생성 이 진행되면 산도가 감소할 수 있으며, 본 연구에서 $\mathrm{MSG}$ 의 존재하에서 젖산균 발효물은 $\mathrm{GABA}$ 생성에 따른 산도의 감소를 보이면서 $\mathrm{GABA}$ 생성 젖산균의 내산성 작용을 나타 내는 것으로 사료되었다.

팽이버섯 발효물의 생균수는 초기 젖산균 스타터 $2.8 \times 10^{7} \mathrm{CFU} / \mathrm{mL}$ 에서 발효 1 일째 $\mathrm{MSG}$ 농도와 관계없이 모든 조건에서 생균수가 $2.1 \times 10^{9} \mathrm{CFU} / \mathrm{mL}$ 으로 가장 높았으 며, 발효 5일째 MSG 0\%, $1 \%$ 첨가한 발효물은 약 $3.6 \times$

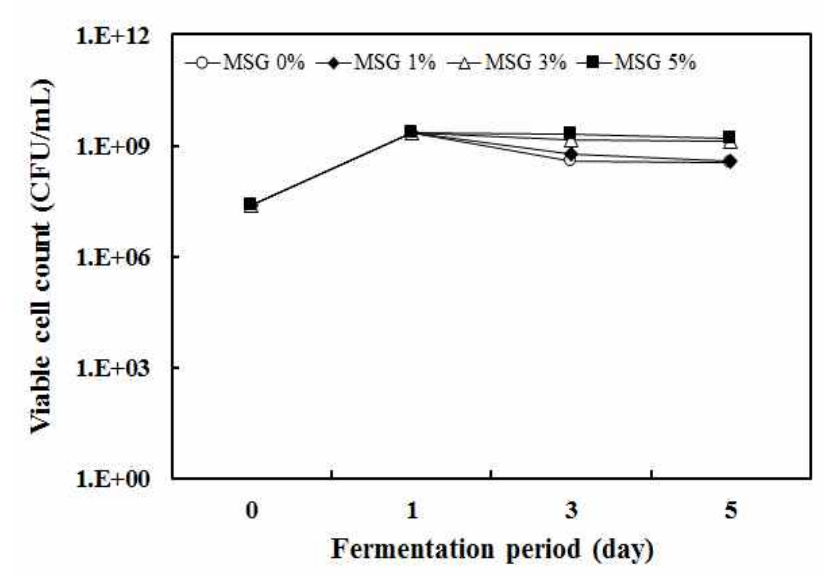

Fig. 3. Effect of MSG concentration on viable cell counts of Flammulina velvipes powder fermented by L. plantarum EJ2014.
$10^{8} \mathrm{CFU} / \mathrm{mL}$ 으로 감소하였으나 MSG $3 \%, 5 \%$ 첨가한 발효 물은 생균수가 $10^{9}$ 으로 계속 유지되는 경향을 보였다(Fig. 3). 이는 $\mathrm{MSG}$ 존재하에 젖산발효 중에 생성된 유기산이 $\mathrm{GABA}$ 합성에 의해서 소실되면서 산도가 감소하는 것이 높은 생균수 유지에 영향을 주는 것으로 사료되었다. 일반 적인 젖산균의 생육곡선에서 발효 기간이 증가하면서 발효 산물의 축적과 영양성분의 결핍으로 생균수가 감소하는 경향을 보이는 것과 대조적으로 $\mathrm{MSG} 3 \%$ 이상으로 첨가된 팽이버섯 발효물의 경우에 젖산균의 생균수를 높게 유지하 는 것으로 나타났다. 또한, 양식 새우의 사료로서 젖산발효 물을 제조하는 과정에서 열풍건조과정중에 보호제로서 MSG 또는 아카시아 검을 첨가한 경우에 사료 펠렛의 젖산 균 생존률은 $75 \%$ 이상이었으며, 상온에서 보관 중에도 높 은 생존율을 나타낸다고 보고하였다(25). 이로서 팽이버섯 분말액의 젖산 발효과정에서 질소원인 $\mathrm{MSG}$ 첨가는 젖산 균의 생육과 생균수 유지에 효과적이며 $\mathrm{GABA}$ 와 같은 기능 성 물질을 생산할 수 있는 전구물질로 활용될 수 있음을 확인하였다.

팽이버섯 $10 \%$ 용액에 첨가된 $\mathrm{MSG}$ 의 농도에 따른 젖산 균의 젖산발효를 통한 $\mathrm{GABA}$ 의 함량 변화를 비교하기 위해 발효물을 원심분리 한 후 얻은 상등액을 TLC를 이용하여 분석한 결과 Fig. 4에서 나타낸 것처럼 배지에 첨가된 MSG 농도에 비례하여 GABA spot이 커지는 것을 확인 할 수 있었다. MSG 0\%에서는 GABA 함량이 아주 미량이었으나 MSG 5\% 첨가한 발효물에서 발효 5일 째 매우 농도가 높은 GABA spot이 나타났다.

팽이버섯 분말액에 $\mathrm{YE}$, glucose, $\mathrm{MSG}$ 를 첨가한 후 젓산 발효 5일 동안 수행하여 얻어진 발효물의 GABA 함량을 HPLC로 정량 분석 한 결과 발효 전 기질인 glutamic acid는 대부분 이용되면서 초기 함량 $3.20 \%$ 에서 거의 소량만이 잔존하고 $2.26 \%$ 의 $\mathrm{GABA}$ 로 전환되는 것으로 나타났다 (Table 1). 젖산균에 의한 GABA생산을 위해서 양송이버섯 에서 분리한 젖산균을 이용하여 $1 \% \mathrm{MSG}$ 존재 하에서

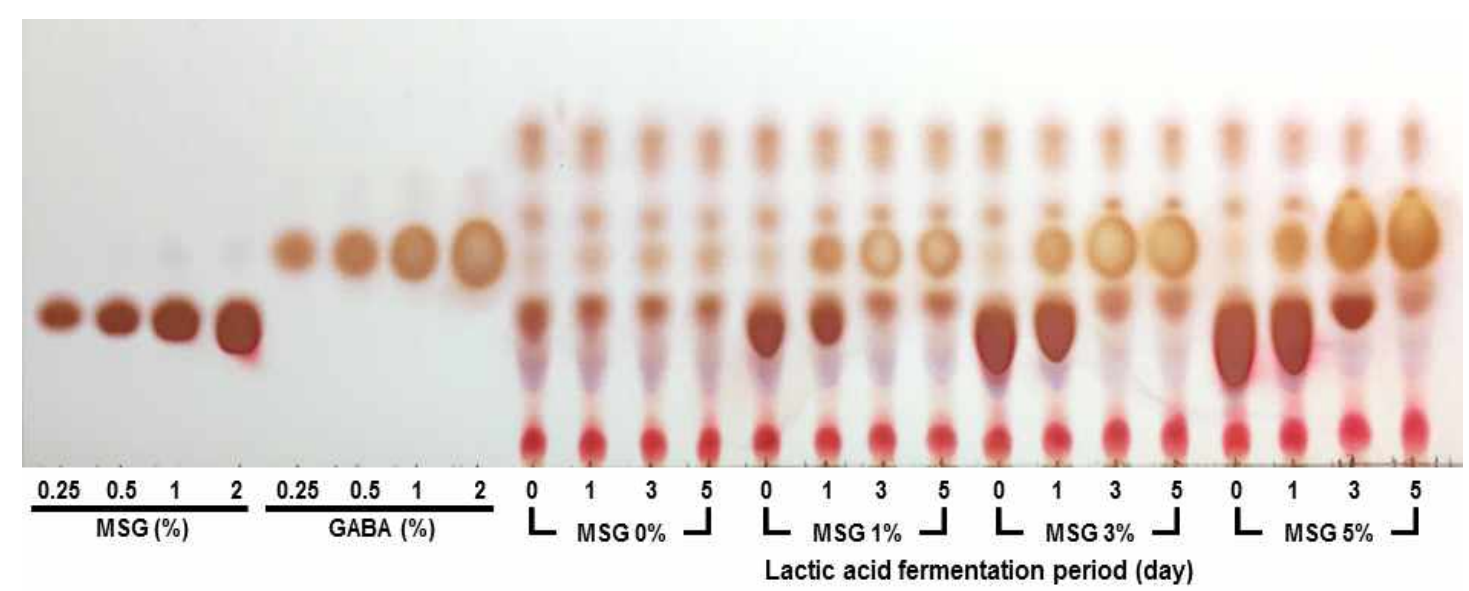

Fig. 4. Effect of MSG concentration on GABA production of Flammulina velutipes powder from fermented L. plantarum EJ2014. 
$0.55 \%$ 정도의 $\mathrm{GABA}$ 를 생산한 연구가 보고되었다(26). 최 근까지 버섯 자체를 배지로 하여 젖산발효에 의한 $\mathrm{GABA}$ 생 산에 관한 연구보고는 없는 것으로 사료되며, 팽이버섯이 함유한 $\mathrm{GAD}$ 효소를 이용하여 GABA생산을 위한 연구에서 $1 \% \mathrm{MSG}$ 수준으로 첨가된 팽이나노분말 용액에서 일부가 $\mathrm{GABA}$ 로 전환됨을 보고(27)한 연구와 비교할 때 본 실험에 서 유용 젖산균을 이용하여 높은 농도의 전구물질 $\mathrm{MSG}$ 를 효과적으로 전환시킴으로서 고농도 GABA생산은 매우 유 용한 연구결과라고 판단되었다.

미생물에 의한 $\mathrm{GABA}$ 의 생성기작은 세포내에서 glutamic acid가 glutamate decarboxylase(GAD)의 효소에 의하여 탈 탄산이 이루어지면서 생산된 GABA가 세포 밖으로 유출되 는 것으로 보고되었다(28). 따라서 $\mathrm{GABA}$ 의 미생물을 이용 한 합성을 위해서는 배지성분에 전구물질인 glutamic acid 가 필요하다. 그러나 고농도의 $\mathrm{GABA}$ 를 함유한 발효소재를 개발하기 위해서는 전구물질인 $\mathrm{MSG}$ 의 첨가와 이를 효과 적으로 생물 전환시키는 발효조건의 최적화가 필요하다. 다양한 식물소재 및 제한배지에서 전구물질인 $\mathrm{MSG}$ 를 $\mathrm{GABA}$ 로 전환시키기 위해서는 발효성 당과 $\mathrm{MSG}$ 를 포함한 아미노산의 농도가 중요한 인자임을 확인하였다(data not shown).

팽이버섯 분말은 최소한의 발효성당과 $5 \%$ 수준의 $\mathrm{MSG}$ 를 첨가함으로서 $\mathrm{GABA}$ 전환이 효과적으로 이루어져 고농 도 GABA를 생산할 수 있었다. 팽이버섯은 다른 식용 및 약용버섯에 비해 GABA 함량이 $72.17 \mathrm{mg} / 100 \mathrm{~g}$ (dry weight) 로 대체로 높은 함량을 나타내고 있다고 보고되었으나(29), 팽이버섯 분말액에 $5 \%$ 수준으로 첨가된 MSG는 효과적으 로 젖산균에 의해 $\mathrm{GABA}$ 로 전환되었으며, 최종 건조된 팽 이버섯 발효물은 약 20 배 이상으로 증가된 고농도의 GABA 를 함유할 수 있었다. 팽이버섯 분말을 함유한 요구르트 발효중에 기질로 첨가한 $1 \% \mathrm{MSG}$ 로부터 일부가 이용되어 $\mathrm{GABA}$ 로 전환되는 연구 보고(27)와 비교할 때 전구물질로 높은 농도인 $5 \% \mathrm{MSG}$ 를 첨가하여 대부분을 $\mathrm{GABA}$ 로 전환 시키는 것은 매우 유익한 연구결과로 사료되었다.

Table 1. Changes in the free amino acids of Flammulina velutipes powder fermented by L. plantarum EJ 2014 for 5 days

\begin{tabular}{ccc}
\hline Fermentation & Glutamic acid $(\%)$ & $\mathrm{GABA}^{1)}(\%)$ \\
\hline Before & $3.20 \pm 0.48^{2)}$ & $0.01 \pm 0.00$ \\
After & $0.03 \pm 0.00$ & $2.26 \pm 0.08$ \\
\hline
\end{tabular}

${ }^{1)} \mathrm{GABA}$, r-aminobutyric acid.

${ }^{2)}$ Values are means $\pm \mathrm{SD}$.

항산화능 측정 결과

DPPH radical 소거 활성법을 이용한 팽이버섯 분말 발효 물의 항산화력을 측정한 결과는 팽이버섯 분말을 발효하기 전 희석배수 $10,50,100$ 에서 각각 $82.22 \%, 60.74 \%, 37.78 \%$
의 저해능을 보이는 것을 알 수 있었으며 $2.20 \mathrm{mg} / \mathrm{mL}$ 의 $\mathrm{IC}_{50}$ 값을 나타내었다. 팽이버섯 분말 발효 후 radical 소거능 은 희석배수 $10,50,100$ 에서 각각 $76.30 \%, 58.52 \%, 43.70 \%$ 로 나타났으며 $\mathrm{IC}_{50}$ 값은 $1.11 \mathrm{mg} / \mathrm{mL}$ 로 $\mathrm{IC}_{50}$ 값이 $4.54 \mu$ $\mathrm{g} / \mathrm{mL}$ 인 항산화제 BHA보다는 소거활성이 낮았지만 팽이 버섯 분말 발효물이 더 적은 농도에서 $50 \%$ 의 항산화 활성 을 보이는 것으로 보아 발효 후에 어느 정도의 전자공여능 이 향상되는 것으로 확인되었다(Table 2).

Table 2. DPPH radical scavenging activity of Flammulina velutipes powder fermented by L. plantarum EJ2014 for 5 days

\begin{tabular}{cccc}
\hline Fermentation & $\begin{array}{c}\text { Dilution } \\
\text { rate }\end{array}$ & $\begin{array}{c}\text { Scavenging } \\
\text { activity (\%) }\end{array}$ & $\mathrm{IC}_{50}{ }^{1)}(\mathrm{mg} / \mathrm{mL})$ \\
\hline \multirow{3}{*}{ Before } & 10 & $82.22 \pm 12.37^{2)}$ & \\
& 50 & $60.74 \pm 3.39$ & $2.20 \pm 0.54$ \\
& 100 & $37.78 \pm 2.22$ & \\
After & 10 & $76.30 \pm 1.28$ & \\
& 50 & $58.52 \pm 4.63$ & $1.11 \pm 0.29$ \\
\hline $\mathrm{BHA}^{3)}$ & 100 & $43.70 \pm 4.63$ & \\
\hline
\end{tabular}

${ }^{1)} \mathrm{IC}_{50}$, concentration required for $50 \%$ reduction of DPPH radical.

${ }^{2)}$ Values are means $\pm \mathrm{SD}$.

${ }^{3}$ BHA, butylated hydroxy anisole.

ABTS potassium persulfate를 암소에 방치하여 ABTS+이 생성되면 시료의 항산화력에 의해 $\mathrm{ABTS}+$ 이 소거되어 radical 특유의 청록색이 탈색 되는데 이를 흡광도 값으로 나타내어 $\mathrm{ABTS}+$ 의 소거 활성능을 측정할 수 있다. 팽이버 섯 분말을 발효하기 전 희석배수 $10,50,100$ 에서 각각 $90.63 \%, 50.51 \%, 35.76 \%$ 의 저해능을 나타내었으며 $\mathrm{IC}_{50}$ 값 은 $3.91 \mathrm{mg} / \mathrm{mL}$ 로 나타나는 것을 확인 할 수 있었다. 팽이버 섯 분말 발효 후 ABTS radical 소거능은 희석배수 10,50 , 100 에서 각각 $90.63 \%, 50.51 \%, 35.76 \%$ 로 나타났으며 $\mathrm{IC}_{50}$ 값은 $2.58 \mathrm{mg} / \mathrm{mL}$ 으로 ABTS 또한 발효 후에 어느 정도의 전자공여능이 높아지는 것을 확인할 수 있었다(Table 3).

Table 3. ABTS radical scavenging activity of Flammulina velutipes powder fermented by L. plantarum EJ2014 for 5 days

\begin{tabular}{cccc}
\hline Fermentation & Dilution rate & Scavenging activity $(\%)$ & $\mathrm{IC}_{50}{ }^{1)}(\mathrm{mg} / \mathrm{mL})$ \\
\hline \multirow{4}{*}{ Before } & 10 & $89.97 \pm 0.92^{2)}$ & \\
& 50 & $53.75 \pm 1.54$ & $3.91 \pm 0.23$ \\
& 100 & $24.27 \pm 1.81$ & \\
\hline \multirow{4}{*}{ After } & 10 & $90.63 \pm 0.63$ & \\
& 50 & $50.51 \pm 3.42$ & $2.58 \pm 0.33$ \\
& 100 & $35.76 \pm 1.40$ & \\
\hline BHA $^{3)}$ & - & - & $4.54 \pm 0.21 \mu \mathrm{\mu g} / \mathrm{mL}$
\end{tabular}

${ }^{1)} \mathrm{IC}_{50}$, concentration required for $50 \%$ reduction of ABTS radical.
${ }^{2)}$ Values are means $\pm \mathrm{SD}$.

${ }^{33} \mathrm{BHA}$, butylated hydroxy anisole. 
$\operatorname{Kang}(30)$ 의 연구에서 팽이버섯 에탄올 추출물의 $\mathrm{DPPH}$ 라디칼 소거능 측정 결과 $\mathrm{IC}_{50}$ 값은 $0.412 \mathrm{mg} / \mathrm{mL}$ 로 보고하 였으며, $\mathrm{ABTS}$ 라디칼 소거 활성을 분석한 결과 $\mathrm{IC}_{50}$ 값은 $0.246 \pm 0.05 \mathrm{mM}$ Trolox eq./mg extract로 보고하였다. Kang 의 보고와는 다르게 항산화능이 감소한 것처럼 보이나 팽이 버섯 분말액의 경우 팽이버섯 분말 $10 \%$ 를 첨가한 분말액 자체를 항산화 측정 한 것으로서 이는 추출 전처리 과정에 서 차이가 있는 것으로 사료되었다.

\section{팽이버섯 분말 발효 조미료 제조}

$10 \%$ 팽이버섯 분말에 $0.5 \% \mathrm{YE}, 1 \%$ glucose, $5 \% \mathrm{MSG}$ 를 첨가한 후 5 일간 젖산발효가 진행되어 고농도 $\mathrm{GABA}$ 를 함유한 팽이버섯 분말 발효물 $30 \mathrm{~g}$ 에 식이섬유 강화 및 건조분말의 흐름성을 개선시키기 위해 볶은 밀기울 분말을 $0,1,3,10 \mathrm{~g}$ 각각 첨가하였다. 최종 혼합물은 $50^{\circ} \mathrm{C}$ 에서 10 시간 열풍건조를 시킨 후 발효 팽이버섯 분말을 제조하 여 발효조미료 소재로 가능성을 평가하였다. 발효 팽이버
섯 분말 제조 시에 볶은 밀기울 분말이 많이 첨가될 수록 볶은 밀기울의 고소한 향은 증가하지만 팽이버섯 분말 발효 물 자체의 조미료 향이 감소하는 것으로 나타났다. 볶은 밀기울을 첨가하지 않고 팽이버섯 발효물 자체만을 열풍 건조하여 조미료를 만들게 되면 풍미는 가장 좋으나 흐름성 이 양호한 분말을 만드는 데는 어려움이 있었다. 이는 팽이 버섯 분말 발효물의 높은 점조성과 수분 흡착능에 따라 건조 발효분말의 흐름이 용이하지 못한 것으로 판단되었 다. 발효 팽이버섯 분말제품의 기호도와 흐름특성을 고려 하였을 때 볶은 밀기울 분말을 $1 \mathrm{~g}$ 첨가하여 조미료 분말을 만드는 것이 기호성과 물성적 특징이 가장 양호한 것으로 판단되었으며 완성된 조미료 사진은 Fig. 5과 같다.

팽이버섯 분말 천연 발효조미료의 이화학적 분석

5 일 동안 젓산발효 된 팽이버섯 분말 발효물 $30 \mathrm{~g}$ 에 볶은 밀기울을 첨가하지 않은 조건과 흐름성을 위해 볶은 밀기울 분말 $1 \mathrm{~g}$ 첨가한 조건을 열풍 건조 시킨 천연 발효조미료의
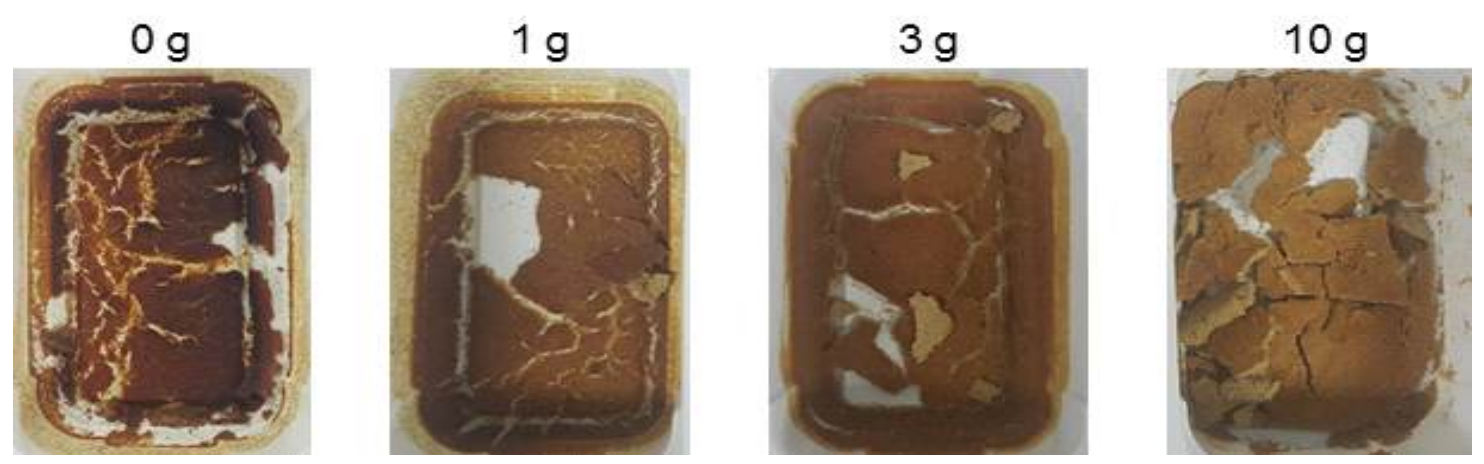

Fig. 5. Hot-air dried mixture of different roasted wheat bran content and Flammulina velutipes powder fermented by L. plantarum EJ2014.

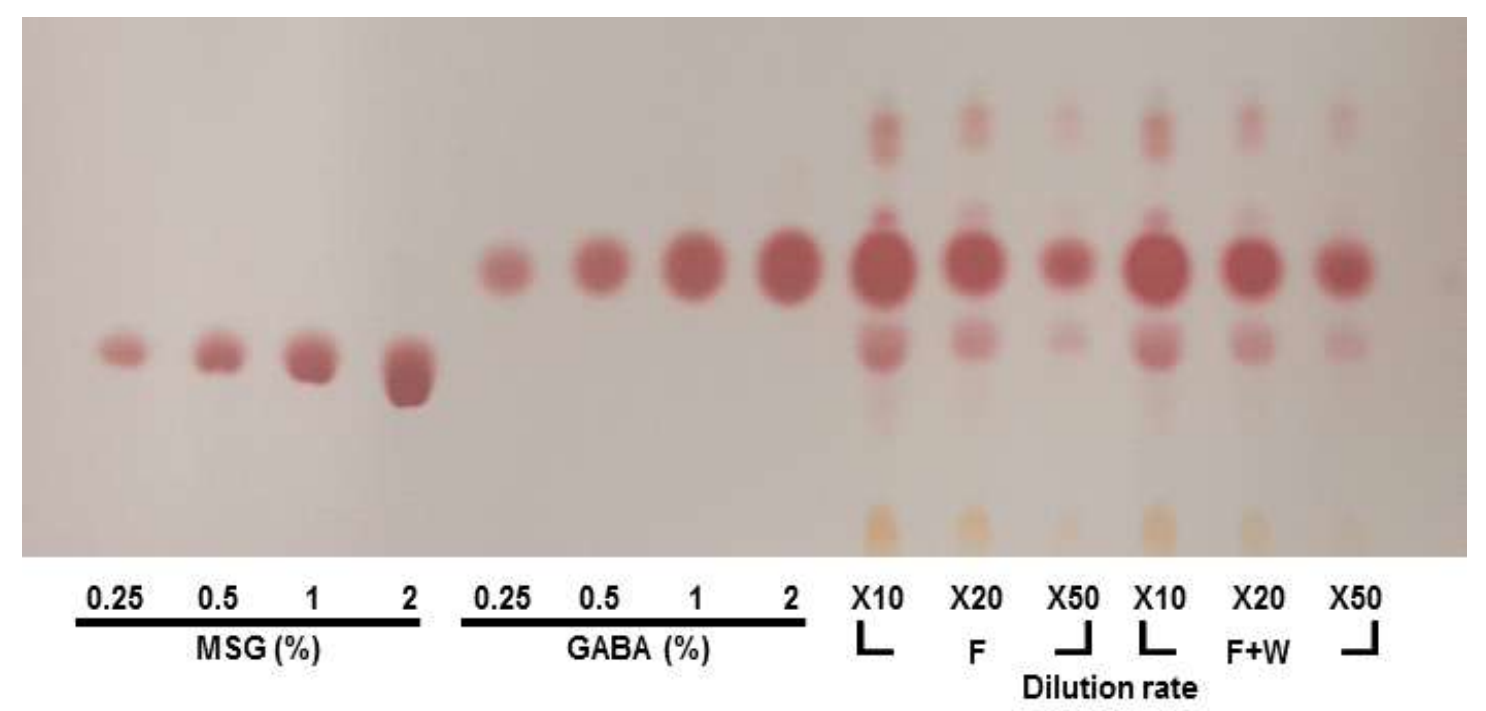

Fig. 6. Changes of GABA content in hot-air dried mixture of roasted wheat bran powder and Flammulina velutipes powder fermented by L. plantarum EJ 2014 .

F, Fermented Flammulina velutipes powder in 5 days; F+W, Fermented Flammulina velutipes powder in 5 days+Roasted wheat bran powder. 
$\mathrm{GABA}$ 의 함량 차이를 비교하였다. 천연 발효조미료를 10 배, 20 배, 50 배 배수별로 희석한 다음 원심분리 한 후 얻은 상등액을 $\mathrm{TLC}$ 를 이용하여 측정 해 본 결과 볶은 밀기울을 첨가하지 않은 조건과 $1 \mathrm{~g}$ 첨가한 조건 둘 다 비슷하게 $\mathrm{GABA}$ 함량이 약 $18 \%$ 로 나타나는 것을 알 수 있었다(Fig. 6). 이상의 결과를 통해 두 조건에서 $\mathrm{GABA}$ 의 함량 차이가 없어 팽이버섯 젖산 발효물 $30 \mathrm{~g}$ 에 흐름성을 위해 볶은 밀기울 분말 $1 \mathrm{~g}$ 첨가한 조건을 천연 발효조미료 제조의 최적조건으로 정하였으며, 얻어진 열 풍건조 분말을 200 배 희석해 유리 아미노산을 $\mathrm{HPLC}$ 를 이용하여 분석하였다. 그 결과 $\mathrm{GABA}$ 함량은 약 $17 \%$, glutamic acid는 약 $0.8 \%$ 가 잔존하는 것을 확인할 수 있었으며, 나트륨 함량은 2,666 $\mathrm{mg} / 100 \mathrm{~g}$ 으로 나타났다. 천연소재 Pharma GABA(Pharma Foods International Co., Ltd., Kyoto, Japan)는 일일 섭취량 $100-200 \mathrm{mg}$ 정도에서 3회 섭취를 통해서 긴장완화 및 수면 불안 해소에 도움을 주는 것이 알려졌으며, GABA의 임상 실험을 통해서 긴장완화 및 면역증진에 효과가 있음이 보고 되었다(31).

일본에서는 고농도 $\mathrm{GABA}$ 함량 소재를 생산하기 위해서 미강 등의 원료를 젖산 발효시켜 $15 \%$ 이상의 $\mathrm{GABA}$ 를 함유 한 최종 분말제품을 높은 가격으로 판매하고 있다. 따라서 팽이버섯 분말의 젖산발효를 통해 얻어진 발효물을 이용한 건조분말은 높은 $\mathrm{GABA}$ 함량을 포함하고 기호성이 우수하 며, probioctic 젖산균을 함유함으로서 천연 발효조미료 원 료로 활용이 가능하다고 판단되었다.

\section{요 약}

팽이버섯 분말을 이용하여 기능성물질인 GABA 및 probiotics를 강화시킨 천연 발효조미료를 개발하기 위해서 L. plantarum EJ2014에 의한 젖산발효 최적화 연구를 수행 하였다. 팽이버섯 분말에 영양성분 $0.5 \% \mathrm{YE}, 1 \%$ glucose, $\mathrm{GABA}$ 전구물질인 $5 \% \mathrm{MSG}$ 를 첨가한 후 $30^{\circ} \mathrm{C}$ 에서 5 일간 젖산발효를 진행한 결과 발효 2 일 동안 $\mathrm{pH}$ 는 6.1 에서 4.4 로 감소하다가 발효 5일에 6.2 로 다시 증가하는 경향을 보였으 며 산도는 발효 2 일 동안 $0.5 \%$ 에서 $1.3 \%$ 로 증가한 후 발효 5 일에 다시 $0.4 \%$ 로 감소하는 경향을 보였다. 생균수는 초기 젖산균 스타터 $2.4 \times 10^{7} \mathrm{CFU} / \mathrm{mL}$ 에서 발효 1 일째 $2.2 \times 10^{9}$ $\mathrm{CFU} / \mathrm{mL}$ 로 증가한 후 5 일 동안 계속 유지되었다. 전구물질 인 MSG는 발효 4 일에 대부분이 이용되면서 약 $2.31 \%$ 농도 의 $\mathrm{GABA}$ 로 전환되었으며 $\mathrm{DPPH}$ radical 소거 활성은 $\mathrm{IC}_{50}$ 값이 $1.24 \mathrm{mg} / \mathrm{mL}$ 로, $\mathrm{ABTS}$ radical 소거 활성에서 $\mathrm{IC}_{50}$ 값은 $1.53 \mathrm{mg} / \mathrm{mL}$ 로 나타나면서, 발효물의 항산화 효과가 증진되 는 것으로 나타났다. 또한 팽이버섯 발효물 $30 \mathrm{~g}$ 에 볶은 밀기울 $1 \mathrm{~g}$ 을 첨가하여 열풍 건조한 천연 발효조미료의 $\mathrm{GABA}$ 함량은 $17 \%$ 로 고농도의 $\mathrm{GABA}$ 를 함유하여 probiotic
기능성이 강화되며 기호성을 갖는 발효조미료 및 건강소재 의 제조가 가능하였다.

\section{감사의 글}

본 결과물은 농림축산식품부의 재원으로 농림수산식품 기술기획평가원의 기술사업화지원사업의 지원을 받아 연 구되었음(No. 314082-3).

\section{References}

1. Tonomura H (1978) Flammulina velutipes. In: The biology and cultivation of edible mushrooms, Chang ST, Hayes WA (Editor), Academic Press, Cambridge, USA, p 410

2. Kim SJ, Han DS (2005) Effect of plants extracts on lipid peroxidation of rat brain tissue induced by reactive oxygen species. Korean J Food Sci Technol, 37, 976-982

3. Tsuda M (1979) Purification and characterization of a lectin from the mushroom, Flammulina velutipes. J Biochem, 86, 1463-1468

4. Kim HS, Son SY, Hwang SY, Hong BS (1999) Purification and characterization of the lectins from mushroom Flammulina velutipes. J Korean Soc Agric Chem Biotechnol, 42, 304-309

5. Komatsu J, Tarekawa $\mathrm{H}$, Nakanishi $\mathrm{K}$, Watanabe $\mathrm{Y}$ (1963) Flammulina velutipes with antitumor activities. J Antibiot, 16, 139-143

6. Lin JY, Lin YJ, Chen CC, Wu HL, Shi GY, Jeng TW (1974) Cardiotoxic protein from edible mushrooms. Nature, 252, 235-237

7. Bernas E, Jaworska G, Kmiecik W (2006) Storage and processing of edible mushrooms. Acta Sci Pol Technol Aliment, 5, 5-23

8. Lee SJ, Park JH, Lee C, Moon BK (2013) Quality characteristics of seasoning with different particle size of Hericium erinaceus powder. Korean J Food Cookery Sci, 29, 741-747

9. Lee LS, Cha HS, Park JD, Jang DJ, Kim SH (2008) Physicochemical properties of mushroom (Flammulina velutipes) cultivated with green tea. J Korean Soc Food Sci Nutr, 37, 190-194

10. Kim HK, Kim MO, Choi MG, Kim KH (2003) Optimization of microwave extraction conditions for Flammulina velutipes by response surface methodology. 
Korean J Food Sci Technol, 35, 222-228

11. Park KY (2012) Increased health functionality of fermented foods. Food Industry Nutrition, 17, 1-8

12. Komatsuzaki N, Shima J, Kawamoto S, Momose H, Kimura $T$ (2005) Production of $\gamma$-aminobutyric acid (GABA) by Lactobacillus paracasei isolated from traditional fermented foods. J Food Microbiol, 22, 497-504

13. Mody I, Dekoninck Y, Otis TS, Soltesz I (1994) Bridging the cleft at GABA synapses in the brain. Trends Neurosci, 17, 517-525

14. Potter WZ, Rudorfer MV, Manji HK (1990) Potential New Pharmacotherapies for refractory depression. Int Rev Psychiatry, 9, 145-169

15. Kang TJ, Oh SH (2007) Production and application of GABA. BioWave, 9, 1-18

16. Li H, Qiu T, Huang G, Cao Y (2010) Production of gamma-aminobutyric acid by Lactobacillus brevis NCL912 using fed-batch fermentation. Microb Cell Fact, 9, 85-91

17. Watanabe Y, Hayakawa K, Ueno H (2011) Effect of co-culturing LAB on GABA production. $\mathrm{J}$ Biol Macromol, 11, 3-13

18. Lee HS, Kwon SY, Lee SO, Lee SP (2016) Production of fermented Omija (Schizandra chinensis) beverage fortified with high content of gamma-amino butyric acid using Lactobacillus plantarum Korean J Food Preserv, 23, 326-334

19. Black FT, Andersen PL, Orskov J, Orskov F, Gaarslev K, Laulund S (1989) Prophylactic efficacy of Lactobacilli on traveler's diarrhoea. Travel Med, 5, 333-335

20. Lee LS, Jung KH, Choi UK, Cho CW, Kim KI, Kim YC (2013) Isolation and identification of lactic acid producing bacteria from kimchi and their fermentation properties of soymilk. J Korean Soc Food Sci Nutr, 42, 1872-1877

21. Sandine WE, Muralidhara KS, Elliker PR, England DC (1972) Lactic acid bacteria in food and health: A review with special reference to enteropathogenic Escherichia coli as well as certain enteric diseases and their treatment with antibiotics and Lactobacilli. J Milk Food Technol, 35, 691-702
22. Baek J, Lee IS, Lee SP (2002) Characterization and fermentation characteristics of Lactic acid bacteria isolated from soybean curd residue (Biji). J Korean Soc Food Sci Nutr, 31, 583-588

23. Cho YR, Chang JY, Chang HC (2007) Production of X-aminobutyric acid (GABA) by Lactobacillus buchneri isolated from kimchi and its neuroprotective effect on neuronal cells. J Microbiol Biotechnol, 17, 104-109

24. Serrazanetti DI, Guerzoni ME, Corsetti A, Vogel R (2009) Metabolic impact and potential exploitation of the stress reactions in Lactobacilli. Food Microbiol, 26, 700-711

25. Wirunpan M, Savedboworn W, Wanchaitanawong $P$ (2016) Survival and shelf life of Lactobacillus lactis 1464 in shrimp feed pellet after fluidized bed drying. Agriculture Natural Resources, 50, 1-7

26. Lee YS, Song TY, Kong WS, Yoon MH (2013) Characterization of $\gamma$-aminobutyric acid (GABA) produced by a lactic acid bacterium from button mushroom bed. J Mushroom Sci Prod, 11, 181-186

27. Shin PG, Kim HC, Yoo YB, Kong WS, Oh YL (2015) Effect of conversion rate of $\gamma$-aminobutyric acid (GABA) by yogurt fermentation with addition of nanoparticle winter mushroom and hydroponic ginseng. J Korean Soc Mush Sci, 13, 334-337

28. Bown AW, Shelp BJ (1997) The metabolism and functions of gamma-aminobutyric acid. Plant Physiol, $115,1-5$

29. Kim HJ, Kim HJ, Jun BS, Cha JY, Kim HK, Cho YS (2001) Analysis of $\gamma$-aminobutyric acid concentrations in Korean plants and mushrooms. Korean J Life Sci, $11,537-542$

30. Kang HW (2012) Antioxidant and anti-inflammatory effect of extracts from Flammulina velutipes (Curtis) Singer. J Korean Soc Food Sci Nutr, 41, 1072-1078

31. Abdou AM, Higashiguchi S, Horie K, Kim M, Hatta $\mathrm{H}$, Yokogoshi H (2006) Relaxation and immunity enhancement effects of gamma-aminobutyric acid (GABA) administration in humans. Biofactors, 26, 201-208 